\title{
Exogenous morphine inhibits the growth of human gastric tumor in vivo
}

\author{
Chunlai Li, Li Li, Yinying Qin, Yage Jiang, Yi Wei, Jing Chen, Yubo Xie \\ Department of Anesthesiology, The First Affiliated Hospital, Guangxi Medical University, Nanning 530021, China \\ Contributions: (I) Conception and design: Y Xie, C Li; (II) Administrative support: Y Xie; (III) Provision of study materials or patients: C Li, L Li; \\ (IV) Collection and assembly of data: C Li, Y Qin, Y Wei; (V) Data analysis and interpretation: C Li, Y Jiang, J Chen; (VI) Manuscript writing: All \\ authors; (VII) Final approval of manuscript: All authors. \\ Correspondence to: Prof. Yubo Xie. Department of Anesthesiology, The First Affiliated Hospital of Guangxi Medical University, No. 6 Shuangyong \\ Road, Nanning 530021, China. Email: xybdoctor@163.com.
}

\begin{abstract}
Morphine is commonly used to relieve severe pain that is often associated with cancer. Previous studies have found that morphine could affect cancer development; however, this effect is poorly understood. To further clarify the anti-cancer potential of morphine for the development of cancer in vivo, we observed how morphine affects the growth of human gastric tumor in a murine xenografting model and the expression of NF- $\kappa \mathrm{B}$ and its downstream target genes (Bcl-2/Bax, cyclind1, and VEGF). The growth of the tumor was evaluated by its growth curves. The mRNA expression levels of NF-kB, Bcl-2/Bax, cyclind1, and VEGF were assessed by semi-quantitative polymerase chain reaction (qPCR). The protein expression of NF- $\mathrm{BB}, \mathrm{Bcl}-2 /$ Bax, cyclind1, and VEGF was detected by immunochemistry staining and western blot. Our data showed that morphine effectively inhibited the tumor growth in the nude mice. Morphine inhibits the expression of NF- $\mathrm{B}, \mathrm{Bcl}-2$, cyclind1, and VEGF while enhancing the expression of Bax in the tumors. Furthermore, the anti-cancer effects of morphine could be reversed by naloxone. The mechanism might be associated with the action of opioid receptors that downregulate the expression of NF- $\kappa$ B leading to the regulation of the downstream target genes (Bcl-2/Bax, cylind1, and VEGF) in the tumors.
\end{abstract}

Keywords: Morphine; gastric cancer; nude mice; tumor growth; NF- $\kappa \mathrm{B}$

Submitted Dec 31, 2019. Accepted for publication Feb 11, 2020.

doi: 10.21037/atm.2020.03.116

View this article at: http://dx.doi.org/10.21037/atm.2020.03.116

\section{Introduction}

Morphine is the most common analgesic used to relieve pain especially in patients with cancer. Since morphine has been widely used to alleviate severe cancer pain, there has been extensive research indicating that morphine can affect tumor development both in vitro and in vivo. For example, morphine promoted Jurkat cell apoptosis through FADD/p53 and NF- $\kappa$ B pathways (1), and morphine dose-dependently induced apoptosis in isolated cultured neuroblastoma cell (2). Our previous study also found that exogenous morphine could inhibit gastric cancer progression in vitro (3). Additionally, in vivo studies have demonstrated that morphine can inhibit tumor angiogenesis in nude mice, thereby inhibiting tumor progression (4).

Although the effects of morphine and other opioids on tumor growth have been discussed in many studies, the specific mechanisms by which morphine influences tumor proliferation, invasion, and metastasis are far from being fully understood. Many researchers have observed that morphine inhibits tumor progression through some pathways in tumor cells. Tegeder et al. reported that morphine can regulate the cell cycle and apoptosis by activation of $\mathrm{p} 53$, inhibiting the cell cycle of tumor growth in adenocarcinoma cells (5). The attenuation of matrix metallopeptidases (MMP) secretion caused by opioids has been discovered to be under the control of the nitric oxide system (6). Moreover, morphine might alter the effect 
of tumor progression through c-Jun $\mathrm{N}$-terminal kinase (JNK)/caspase pathway and HIF-1alpha/p38MAPK pathway $(2,3)$. In our previous study, we proposed that the mechanism by which morphine inhibits the progression of gastric cancer in vitro could have associations with the triggering of apoptosis and the inhibition of NF- $\kappa B$. $\mathrm{NF}-\kappa \mathrm{B}$ is an important nuclear transcription factor that severely affects the regulation of a numerous downstream target genes associated with apoptosis, tumorigenesis, immune diseases, and inflammation (7-9). There is also evidence that the inhibition of NF- $\kappa \mathrm{B}$ might suppress tumor growth (10).

In the study presented here, we investigated the effects of exogenous morphine on gastric cancer progression in vivo and the expression of $\mathrm{NF}-\kappa \mathrm{B}$ and its downstream target genes, Bcl-2/Bax, cyclind1, and VEGF, which are related to apoptosis, cell cycle, and tumorigenesis, respectively, in a nude mice xenografting model using human gastric cancer MGC-803 cells. The goals of our research are to explore the further possible mechanism of morphine affecting tumor progression and to provide some practical suggestions for the treatment of cancer pain.

\section{Methods}

\section{Cell culture}

We obtained MGC-803 cells from the Cell Bank of Chinese Academy of Sciences (Shanghai, China), which were then cultured in Dulbecco's modified Eagle's medium (DMEM) (Invitrogen, Gaithersburg, MD, USA) supplemented with $10 \%$ heat-inactivated fetal bovine serum (FBS) (HyClone, Logan, UT, USA), $75 \mathrm{U} / \mathrm{mL}$ streptomycin and $100 \mathrm{U} / \mathrm{mL}$ penicillin at $37{ }^{\circ} \mathrm{C}$ and $5 \% \mathrm{CO}_{2}$ in a standard humidified incubator.

\section{Animals}

We obtained 40 male Bagg Albino/c (BALB) nude mice with weight ranging between $20-25 \mathrm{~g}$ and the age ranging from 5-6 weeks from the Experimental Animal Center of Guangxi Medical University (Nanning, China). The environmental temperature and relative humidity were kept at $25{ }^{\circ} \mathrm{C}$ and $50 \%$, respectively. The care and treatment of all animals were in keeping with the guidelines of the Experimental Animal Management Institution of Guangxi Medical University.

\section{Nude mice xenograft model}

To determine the effects of morphine on the development of human gastric cancer MGC-803 cell line in vivo, MGC-803 cells $\left(2 \times 10^{6}, 200 \mu \mathrm{L}\right.$ of PBS) were injected subcutaneously into the left flanks of the mice. The mice were randomly divided into 8 groups ( $\mathrm{n}=5$ each): group $\mathrm{C}$ (control group), group NS (normal saline group), group $M$ (morphine group), group $\mathrm{N}$ (naloxone group), and group MN (morphine and naloxone group). Group C did not receive any treatment while the corresponding control group (group NS) was treated with normal saline. The mice in group $M, M 1, M 2, M 3$, and M4 were injected with $5 \mathrm{mg} / \mathrm{kg}$ morphine, $10 \mathrm{mg} / \mathrm{kg}$ morphine, $20 \mathrm{mg} / \mathrm{kg}$ morphine, and $40 \mathrm{mg} / \mathrm{kg}$ morphine, respectively. Group $\mathrm{N}$ was treated with $1 \mathrm{mg} / \mathrm{kg}$ naloxone. Group MN was treated with $1 \mathrm{mg} / \mathrm{kg}$ naloxone $30 \mathrm{~min}$ prior to morphine injection $(20 \mathrm{mg} / \mathrm{kg})$. The solutions for all the groups were injected intraperitoneally using a microsyringe every 2 days.

\section{Tumor measurement}

The tumor volume was determined using a caliper and calculated by the following formula: length $\times$ width $^{2} / 2$. All the groups were measured at days 2, 6, 10, and 14 to obtain tumor growth curves. Animals were sacrificed after the 14 days, and the tumors were extirpated and compared for volume and weight.

\section{Immunochemistry staining}

Paraffin tissue sections were deparaffinized using turpentine with rehydration occurring in a descending ethanol series following normal procedures. Heatinduced antigen retrieval was completed in $0.01 \mathrm{~mol} / \mathrm{L}$ citrate buffer at $100{ }^{\circ} \mathrm{C}$ for $20 \mathrm{~min}$. Antigen retrieval with enzyme digestion was completed in $0.1 \%$ trypsin at $37{ }^{\circ} \mathrm{C}$ for $25 \mathrm{~min}$. The sections were subsequently blocked with serum for $30 \mathrm{~min}$ and incubated with primary antibodies (anti-NF-kB, anti-Bcl-2, anti-Bax, anti-cyclind1, or antiVEGF) (CST, USA) for 1 to 2 hours at $37^{\circ} \mathrm{C}$. After being washed, the sections underwent incubation with horseradish peroxidase-goat anti-rabbit antibody at $37^{\circ} \mathrm{C}$ for 30 minutes. The peroxidase reaction was performed using 3,3-diaminobenzidine (DAB) solution in $\mathrm{DAB}$ buffer substrate. Sections were visualized with DAB, counterstained with hematoxylin, mounted in neutral gum, 
and analyzed with a bright-field microscope.

\section{Real-time quantitative polymerase chain reaction (RT- qPCR) analysis}

Total RNA was extracted with TRIzol (Invitrogen Life Technologies, Carlsbad, CA, USA). RNA $(2.5 \mu \mathrm{g})$ was reverse transcribed with the Prime Script RT Master Mix Kit (Takara, Tokyo, Japan) following the manufacturer's protocol. The genes were amplified from cDNA by PCR. The cDNA was amplified with PCR using the following specific primers: Bcl2 forward 5'- GACTTCGCCGAGATGTCCAG -3', reverse 5'-CATCCCAGCCTCCGTTATCC-3'; Bax forward 5'-AAGAAGCTGAGCGAGTGT -3', reverse 5'-CCGGAGGAAGTCCAATGTC-3'; cyclind1 forward 5' - CCCTCGGTGTCCTACTTCAA -3', reverse 5'GGGGATGGTCTCCTTCATCT -3'; VEGF forward 5'- TCGAACTTTGACAGCGACAAGAA -3', reverse 5'TCAGGGCGAGGACCATAGAGG -3', and GAPDH forward 5'- CGGGAAGCTTGTCATCAATGG-3', reverse 5'- GGCAGTGATGGCATGGACTG-3'. PCR was performed in the following steps: denaturation $(5 \mathrm{~min}$ at $94{ }^{\circ} \mathrm{C}$ ), amplification $\left(95^{\circ} \mathrm{C}\right.$ for $30 \mathrm{~s}, 54-58^{\circ} \mathrm{C}$ for $1 \mathrm{~min}$, and $72{ }^{\circ} \mathrm{C}$ for $1 \mathrm{~min}$ ), and extension $\left(72{ }^{\circ} \mathrm{C}\right.$ for $\left.5 \mathrm{~min}\right)$. RTqPCR was conducted with the One Step SYBR ${ }^{\circledR}$ Prime Script ${ }^{\circledR}$ PLUS RT-RNA PCR Kit (TaKaRa Biotechnology, Dalian, China). The GAPDH mRNA level was used as an internal control. The relative expression of mRNA was assessed using the $2^{-\triangle \Delta C T}$ method.

\section{Western blot analysis}

The proteins from tumor tissues were washed with $1 \times$ PBS and lysed with RIPA buffer consisting of protease inhibitors (Beyotime Biotechnology, Shanghai, China). Afterwards, the proteins were collected and extracted, and their concentrations were evaluated (BCA Protein Assay Kit, Beyotime Biotechnology Co., Ltd., Haimen, China). The samples $(20 \mu \mathrm{g} / \mathrm{lane})$ were electrophoresed by $12 \%$ SDS-PAGE and electrically transferred onto polyvinylidene fluoride (PVDF) membranes (Millipore, USA) in transfer buffer. Following being blocked with $5 \%$ bovine serum albumin in Tris-buffered saline/Tween 20 (TBST) for $2 \mathrm{~h}$ at room temperature, the membranes underwent incubation at $4{ }^{\circ} \mathrm{C}$ overnight using the following primary antibodies: anti-NF-кB (\#4764, CST, USA), anti-Bcl-2 (\#3498, CST, USA), anti-Bax (\#5023, CST, USA), anti-cyclind1 (\#2978,
CST, USA), anti-VEGF (\#2479, CST, USA), and GAPDH (ab181602, Abcam). Following incubation with the suitable primary antibodies, the membranes were washed 3 times and incubated for $1.5 \mathrm{~h}$ at room temperature using a horseradish peroxidase (HRP)-conjugated goat antirabbit IgG secondary antibody (ab205718, Abcam). The quantification of immunoreactive intensity was visualized with ImageJ software (version 2.1.4.7; National Institutes of Health, Bethesda, MD, USA). The relative amounts of protein in each lane were obtained after normalization with the GAPDH values in the same lane.

\section{Statistical analysis}

Date are presented as the mean \pm SEM and were calculated with one-way analysis of variance (ANOVA) and $t$ test with Dunnett's comparison using Prism (version 6.0; GraphPad Software Inc., San Diego, CA, USA). A P value $<0.05$ was taken as indicating a statistically significant difference.

\section{Results}

Morphine inhibits growth of human gastric cancer in nude mice.

The growth of the tumor was evaluated by the growth curves of the tumor. According to the results, the tumor growth in group M (M1, M2, M3, M4) were obviously inhibited in comparison to those in groups $\mathrm{C}, \mathrm{NS}, \mathrm{N}$, and $\mathrm{MN}(\mathrm{P}<0.05)$ (Figure 1).

Morphine reduced the expression levels of bcl-2, cyclind1, and VEGF, while raising Bax expression.

Cyclind1, bcl-2, Bax, and VEGF were selected to estimate the expression differences between the tumors in different treatment groups by RT-qPCR. According to the results, cyclind1, Bcl-2, and VEGF mRNA of tumors in group M (M1, M2, M3, M4) were obviously inhibited in comparison to those in groups $\mathrm{C}, \mathrm{NS}, \mathrm{N}$, and $\mathrm{MN}$, while the expression of $\mathrm{Bax}$ was increased $(\mathrm{P}<0.05)$ (Figure 2).

Morphine decreased the expression of NF- $\kappa \mathrm{B}, \mathrm{Bcl}-2$, cyclind1, and VEGF and increased the expression of Bax.

The expression of protein in tumor tissue was detected by immunochemistry staining.

As shown in Figure 3, the positive cells of NF- $\kappa$ B, $\mathrm{Bcl}-2$, cyclind1, and VEGF in group $M$ were more than those in group $\mathrm{C}, \mathrm{NS}, \mathrm{N}$, and $\mathrm{MN}$, while the number of positive cells of Bax in group $M$ was less than those in groups $\mathrm{C}, \mathrm{NS}, \mathrm{N}$, and $\mathrm{MN}$. $(\mathrm{P}<0.05)$. The related protein changes of tumor tissue were detected by a western blot 

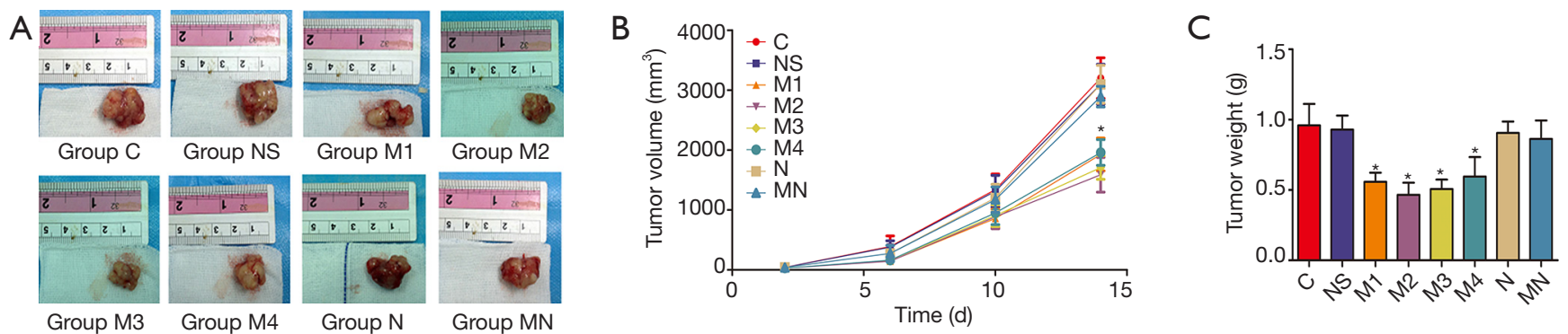

Figure 1 Growth curves of tumor xenografts in nude mice. (A) The growth of the tumor was observed on days 2, 6, 10, and 14. (B) The mean tumor size of mice in each group. (C) The tumor weight of mice in each group on day 14. Data are expressed as the mean \pm SEM. *, P<0.05 vs. group C, NS, N and MN. Group C, control; Group NS, 1.5 mL/kg NS; Group M1, 5 mg/kg morphine; Group M2, 10 mg/kg morphine; Group M3, 20 mg/kg morphine; Group M4, 40 mg/kg morphine; Group N, 1 mg/kg naloxone; Group MN, 20 mg/kg morphine and $1 \mathrm{mg} / \mathrm{kg}$ naloxone.
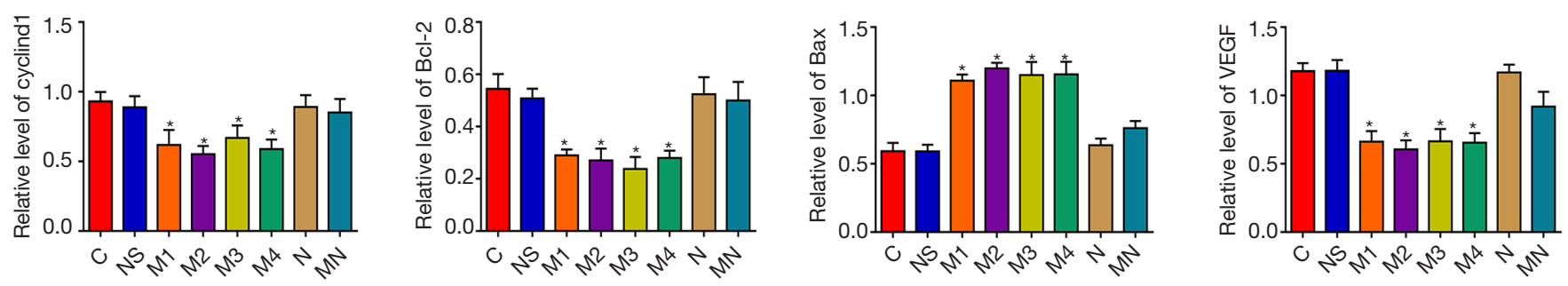

Figure 2 Morphine induces Bcl-2, cyclind1, and VEGF mRNA expression downregulation and upregulation of Bax in tumors of nude mice. Data are expressed as the mean \pm SEM. * $\mathrm{P}<0.05$ vs. group C, NS, N and MN. Group C, control; Group NS, $1.5 \mathrm{~mL} / \mathrm{kg}$ NS; Group M1, 5 mg/kg morphine; Group M2, 10 mg/kg morphine; Group M3, 20 mg/kg morphine; Group M4, 40 mg/kg morphine; Group N, 1 mg/kg naloxone; Group MN, $20 \mathrm{mg} / \mathrm{kg}$ morphine and $1 \mathrm{mg} / \mathrm{kg}$ naloxone.

assay. According to the results, NF- $\kappa \mathrm{B}, \mathrm{Bcl}-2$, cyclind1, and VEGF protein of tumors in group $M$ were lower, while that of Bax was higher compared with groups $\mathrm{C}, \mathrm{NS}, \mathrm{N}$, and $\mathrm{MN},(\mathrm{P}<0.05)$ (Figure 4).

\section{Discussion}

The incidence and death rate of cancer are increasing, and cancer pain is one of the most common clinical symptoms in the middle and late stages of cancer. Morphine, a representative of potent opioids, is frequently used for moderate to severe cancer pain. Previously, morphine and other opiates were found to have an anti-cancer effect, including the promotion of cell death in tumor cells. Kawase et al. (11) reported that opiates could induce cell death in human oral tumor cell lines. While relieving pain, morphine significantly inhibited melanoma growth and lung metastasis in a mouse model of cancer pain (12). Koodie et al. (13) also demonstrated that morphine could inhibit migration and suppress angiogenesis associated with tumor growth in mice. On the other hand, morphine was also found to increase the proliferation of tumor cells and promote angiogenesis, leading to the acceleration of tumor progression. Additionally, morphine was also shown to induce cancer recurrence by disturbing the behavior of the regulatory $\mathrm{T}$ cells (14). In another study, morphine promotes the angiogenesis of postoperative recurrent tumors and metastasis by PI3K-c-Myc pathway (15). Therefore, the effects of morphine on cancer development have been a controversial topic affecting its clinical use, and the way that morphine influences cancer growth is not clear.

Our previous study showed that morphine could inhibit human gastric tumor cells in vitro, and the effects might be related to the activation of caspases and the inhibition of NF- $\mathrm{\kappa B}$ and survivin. In the current study, we observed how morphine affected the growth of human gastric tumor in a murine MGC-803 cell xenografting model and the expression of NF- $\mathrm{NB}$ and some of its downstream target genes. Our data showed that morphine effectively inhibited the tumor growth in the nude mice. Morphine 


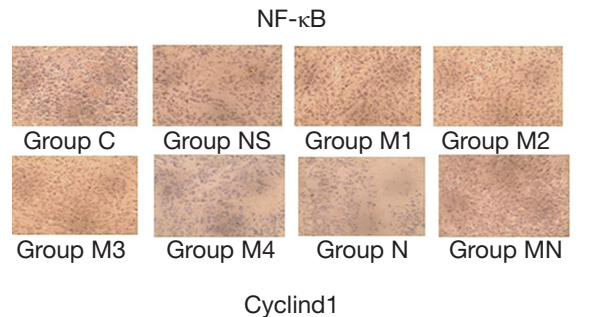

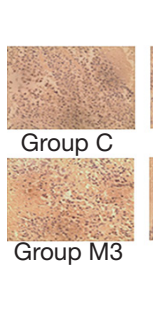

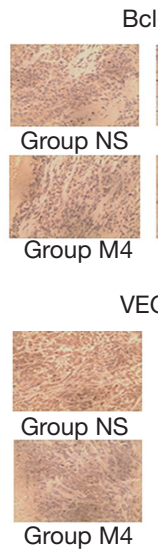

Bcl-2

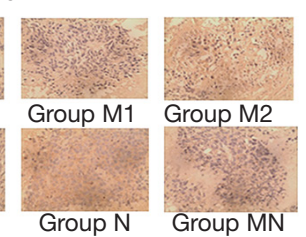

VEGF
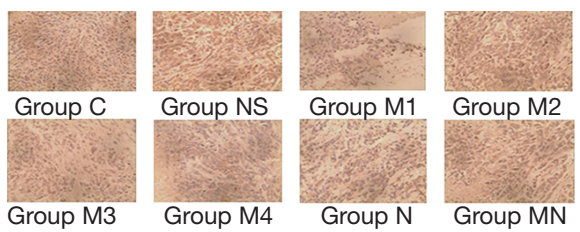

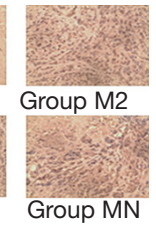

Bax
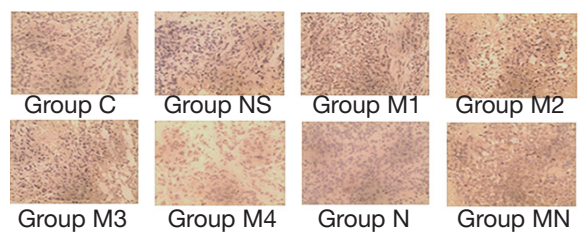

Group M4

Group N

Group MN
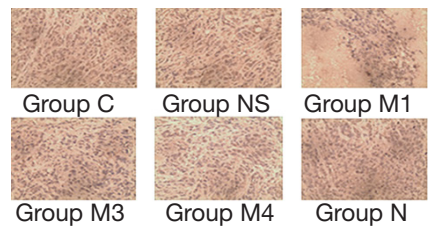

Figure 3 Morphine increases Bax protein expression while NF- $\mathrm{B}, \mathrm{Bcl}-2$, cyclind1, and VEGF are decreased in tumors of the nude mice using immunochemistry staining. Group C, control; Group NS, $1.5 \mathrm{~mL} / \mathrm{kg} \mathrm{NS}$; Group M1, $5 \mathrm{mg} / \mathrm{kg}$ morphine; Group M2, $10 \mathrm{mg} / \mathrm{kg}$ morphine; Group M3, 20 mg/kg morphine; Group M4, 40 mg/kg morphine; Group N, 1 mg/kg naloxone; Group MN, 20 mg/kg morphine and $1 \mathrm{mg} / \mathrm{kg}$ naloxone.
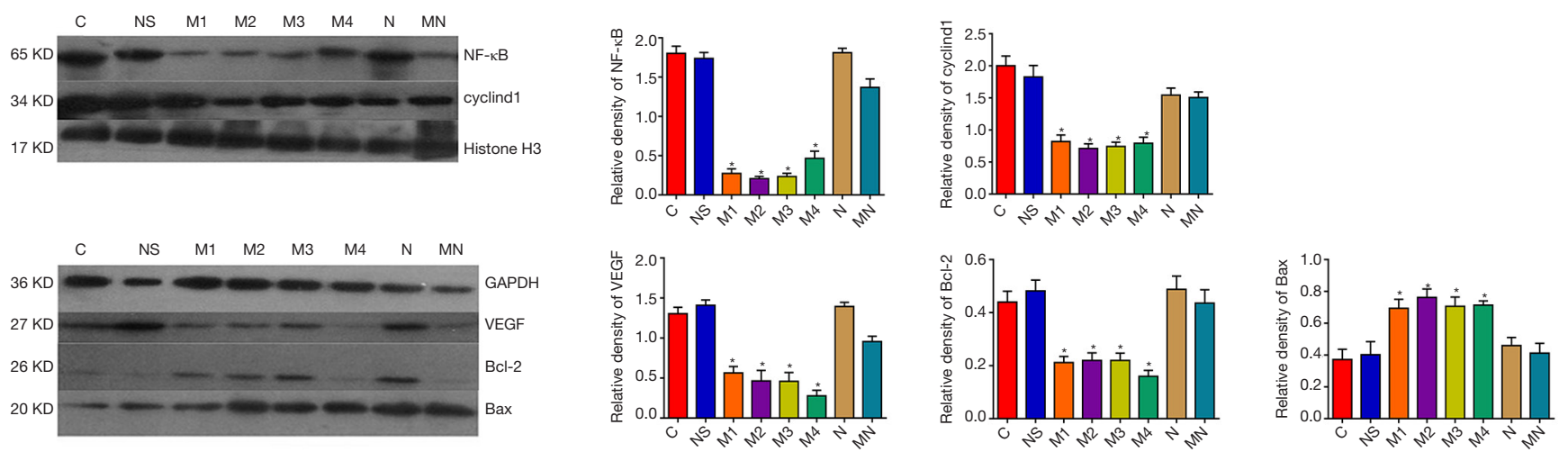

Figure 4 Morphine increases Bax protein expression while NF- $\mathrm{B}, \mathrm{Bcl}-2$, cyclind1. and VEGF are decreased in tumors of the nude mice through western blot. Data are expressed as the mean \pm SEM. *, $\mathrm{P}<0.05$ vs. group C, NS, N and MN. Group C, control; Group NS, $1.5 \mathrm{~mL} / \mathrm{kg} \mathrm{NS}$; Group M1, $5 \mathrm{mg} / \mathrm{kg}$ morphine; Group M2, $10 \mathrm{mg} / \mathrm{kg}$ morphine; Group M3, $20 \mathrm{mg} / \mathrm{kg}$ morphine; Group M4, $40 \mathrm{mg} / \mathrm{kg} \mathrm{morphine;} \mathrm{Group} \mathrm{N,}$ $1 \mathrm{mg} / \mathrm{kg}$ naloxone; Group MN, $20 \mathrm{mg} / \mathrm{kg}$ morphine and $1 \mathrm{mg} / \mathrm{kg}$ naloxone.

downregulated the expression of NF- $\mathrm{BB}, \mathrm{Bcl}-2$, cyclind1, and VEGF, while upregulating Bax in the tumors.

$\mathrm{NF}-\mathrm{\kappa B}$ activation may promote tumor growth, and the inhibition of NF- $\kappa \mathrm{B}$ could suppress the development of cancer. A few other studies have also speculated that the mechanism of the anti-cancer effects of morphine might involve NF- $\kappa \mathrm{B}$ inhibition (16). Bcl-2 and Bax belong to the Bcl family which is critically involved in the regulation of apoptosis, with Bcl-2 inhibiting apoptosis and Bax promoting apoptosis. The decrease of $\mathrm{Bcl}-2 / \mathrm{Bax}$ ratio could induce the apoptosis (17). In our study, morphine downregulated the expression of Bcl-2 while Bax expression was upregulated, which might induce apoptosis of the cancer cells in the tumor and result in the inhibition of tumor growth. Cyclind1 is one of the regulators of the cell cycle, the overexpression of which will result in malignant cell proliferation $(18,19)$. In this study, morphine inhibited the expression of cyclind1, and reduced cell proliferation. Meanwhile, VEGF, which regulates vascular development, plays an important role in tumor angiogenesis, bolsters the forming of new blood vessels to maintain tumor growth, and triggers endothelial cell proliferation and metastasis (20-22). Balasubramanian et al. (23) found that morphine could inhibit hypoxia-induced VEGF expression in 
cardiac myocytes and endothelial cells, thus inhibiting the neovascularization caused by myocardial ischemia. Koodie et al. (4) observed that administration of morphine in clinically relevant analgesic doses significantly reduce tumor cell-induced angiogenesis in a murine Lewis lung carcinoma tumor model. As Bcl-2/Bax, clind1and, VEGF are the downstream target genes of $\mathrm{NF}-\kappa \mathrm{B}$, the potent regulation of these genes by morphine may inhibit NF- $\kappa \mathrm{B}$.

Recently, many researchers have found that the $\mu$-opioid receptor (MOR) might regulate cancer progression (24-26). Both MOR knockout and silent MOR expression can markedly attenuated tumor growth and metastasis (27). In the case where tumors that express MOR and have no loss of p53 mutations, opioid receptor antagonists increase the inhibitory effect of morphine on tumor growth (5). These experimental data imply that the MOR is involved in tumor growth and metastasis. Herein, our study data showed that morphine could inhibit tumor progression, while the opioid receptor antagonist, naloxone, could reverse the effects of morphine on tumor progression. This finding suggests that opioid receptors might be involved in morphine's inhibition of tumor development in the MGC803 cell xenograft model.

\section{Conclusions}

In summary, morphine could inhibit human gastric tumor growth in vivo: the morphine signals could be transduced by opioid receptors and then downregulate the expression of $\mathrm{NF}-\kappa \mathrm{B}$, leading to the regulation of the downstream target genes (Bcl-2/Bax, clind1, and VEGF) and the eventual inhibition of tumor growth.

\section{Acknowledgments}

Funding: This work was supported by the Natural Science Foundation of China (No. 81560500 and 81160289).

\section{Footnote}

Conflicts of Interest: The authors have no conflicts of interest to declare.

Ethical Statement: The authors are accountable for all aspects of the work in ensuring that questions related to the accuracy or integrity of any part of the work are appropriately investigated and resolved.
Open Access Statement: This is an Open Access article distributed in accordance with the Creative Commons Attribution-NonCommercial-NoDerivs 4.0 International License (CC BY-NC-ND 4.0), which permits the noncommercial replication and distribution of the article with the strict proviso that no changes or edits are made and the original work is properly cited (including links to both the formal publication through the relevant DOI and the license). See: https://creativecommons.org/licenses/by-nc-nd/4.0/.

\section{References}

1. Yin D, Woodruff M, Zhang Y, et al. Morphine promotes Jurkat cell apoptosis through pro-apoptotic FADD/P53 and anti-apoptotic PI3K/Akt/NF-kappaB pathways. J Neuroimmunol 2006;174:101-7.

2. Fiore G, Ghelardini C, Bruni G, et al. Differentiation state affects morphine induced cell regulation in neuroblastoma cultured cells. Neurosci Lett 2013;555:51-6.

3. Qin Y, Chen J, Li L, et al. Exogenous morphine inhibits human gastric cancer MGC- 803 cell growth by cell cycle arrest and apoptosis induction. Asian Pac J Cancer Prev 2012;13:1377-82.

4. Koodie L, Ramakrishnan S, Roy S. Morphine suppresses tumor angiogenesis through a HIF-1alpha/p38MAPK pathway. Am J Pathol 2010;177:984-97.

5. Tegeder I, Grösch S, Schmidtko A, et al. G proteinindependent G1 cell cycle block and apoptosis with morphine in adenocarcinoma cells: involvement of p53 phosphorylation. Cancer Res 2003;63:1846-52.

6. Gach K, Szemraj J, Wyrębska A, et al. The influence of opioids on matrix metalloproteinase-2 and -9 secretion and mRNA levels in MCF-7 breast cancer cell line. Mol Biol Rep 2011;38:1231-6.

7. Sokolova O, Naumann M. NF-кB Signaling in Gastric Cancer. Toxins (Basel). 2017. doi: 10.3390/toxins9040119.

8. Chen XL, Hong LL, Wang KL, et al. Deregulation of CSMD1 targeted by microRNA-10b drives gastric cancer progression through the NF- $\mathrm{NB}$ pathway. Int J Biol Sci 2019;15:2075-86.

9. Sun SC. The non-canonical NF- $\kappa$ B pathway in immunity and inflammation. Nat Rev Immunol 2017;17:545-58.

10. Patel M, Horgan PG, Mcmillan DC, et al. NF- $\kappa B$ pathways in the development and progression of colorectal cancer. Translational Research 2018;197:43-56.

11. Kawase M, Sakagami H, Furuya K, et al. Cell deathinducing activity of opiates in human oral tumor cell lines. 
Anticancer Res 2002;22:211-4.

12. Sasamura T, Nakamura S, Iida Y, et al. Morphine analgesia suppresses tumor growth and metastasis in a mouse model of cancer pain produced by orthotopic tumor inoculation. Eur J Pharmacol 2002;441:185-91.

13. Koodie L, Yuan H, Pumper JA, et al. Morphine inhibits migration of tumor-infiltrating leukocytes and suppresses angiogenesis associated with tumor growth in mice. Am J Pathol 2014,184:1073-84.

14. Gong L, Dong C, Ouyang W, et al. Regulatory T cells: a possible promising approach to cancer recurrence induced by morphine. Med Hypotheses 2013,80:308-10.

15. Cheng S, Guo M, Liu Z, et al. Morphine promotes the angiogenesis of postoperative recurrent tumors and metastasis of dormant breast cancer cells. Pharmacology 2019;104:276-86.

16. Sueoka E, Sueoka N, Kai Y, et al. Anticancer activity of morphine and its synthetic derivative, KT-90, mediated through apoptosis and inhibition of NF-kappaB activation. Biochem Biophys Res Commun 1998;252:566-70.

17. Kaparou M, Choumerianou D, Perdikogianni C, et al. Enhanced levels of the apoptotic BAX/BCL-2 ratio in children with acute lymphoblastic leukemia and high-risk features. Genet Mol Biol 2013,36:7-11.

18. Seiler R, Thalmann GN, Rotzer D, et al. CCND1/ CyclinD1 status in metastasizing bladder cancer: a prognosticator and predictor of chemotherapeutic response. Mod Pathol 2014;27:87-95.

19. Yu J, Wang X, Lu Q, et al. Extracellular 5'-nucleotidase (CD73) promotes human breast cancer cells growth

Cite this article as: $\mathrm{Li} \mathrm{C,} \mathrm{Li} \mathrm{L,} \mathrm{Qin} \mathrm{Y,} \mathrm{Jiang} \mathrm{Y,} \mathrm{Wei} \mathrm{Y,} \mathrm{Chen}$ J, Xie Y. Exogenous morphine inhibits the growth of human gastric tumor in vivo. Ann Transl Med 2020;8(6):385. doi: 10.21037/atm.2020.03.116 through AKT/GSK-3 $\beta / \beta$-catenin/cyclinD1 signaling pathway. Int J Cancer 2018;142:959-67.

20. Itatani Y, Kawada K, Yamamoto T, et al. Resistance to Anti-Angiogenic Therapy in Cancer-Alterations to Anti-VEGF Pathway. Int J Mol Sci 2018. doi: 10.3390/ ijms19041232.

21. Li X, Feng Y, Liu J, et al. Epigallocatechin-3-Gallate Inhibits IGF-I-Stimulated Lung Cancer Angiogenesis through Downregulation of HIF-1 $\alpha$ and VEGF Expression. J Nutrigenet Nutrigenomics 2013;6:169-78.

22. Li X, Gao Y, Li J, et al. FOXP3 inhibits angiogenesis by downregulating VEGF in breast cancer. Cell Death Dis 2018;9:744.

23. Balasubramanian S, Ramakrishnan S, Charboneau R, et al. Morphine sulfate inhibits hypoxia-induced vascular endothelial growth factor expression in endothelial cells and cardiac myocytes. J Mol Cell Cardiol 2001;33:2179-87.

24. Moss J, Rosow CE. Development of peripheral opioid antagonists' new insights into opioid effects. Mayo Clin Proc 2008;83:1116-30.

25. Wang CZ, Li XL, Sun S, et al. Methylnaltrexone, a peripherally acting opioid receptor antagonist, enhances tumoricidal effects of 5-Fu on human carcinoma cells. Anticancer Res 2009;29:2927-32.

26. Singleton PA, Moss J. Effect of perioperative opioids on cancer recurrence: a hypothesis. Future Oncol 2010;6:1237-42.

27. Mathew B, Lennon FE, Siegler J, et al. The novel role of the mu opioid receptor in lung cancer progression: a laboratory investigation. Anesth Analg 2011;112:558-67. 